\title{
Effects of Substrate and Rootone on the Rooting of (Mentha spicata), Mentha x piperita, and Nepeta cataria
}

\author{
Ji An $\operatorname{Rim}^{1}$ and Eu Jean Jang ${ }^{2}$ * \\ ${ }^{1}$ Department of Horticultural Biotechnology, Graduate of Life and Environmental Sciences, Korea University, Seoul 02841, South Korea \\ ${ }^{2}$ Department of Horticulture and Biotechnology, Graduate School of Life and Environmental Science, Korea University, Seoul 02841 , \\ South Korea
}

\begin{abstract}
Effects of substrates, non-aggregated medium and Rootone on the rooting of spearmint (Mentha spicata), peppermint (Mentha $\mathrm{x}$ piperit) and catmint (catnip:Nepeta cataria) were investigate and results were as follow. Five types of substrate (saproilite $(S)$, peatmoss (P), S:P 75:25, S:P 50:50, S:P 25:75v/v) were used as rooting media. In the rooting rate and number of roots, peppermint and catmint had higher values in saprolite with significant, but spearmint was shown the better result in S:P 25:75 mixed substrate than saprolite without significances. Root length of spearmint was promoted in mixed substrate of S:P 50:50 and 75:25, and catmint was better in saprolite substrate. Rooting rate and number of roots were shown more decreased in single peatmoss substrate and mixed substrate than saproilte. The effects of aggregated medium (S) and non aggregated medium (tap water) on the rooting of different stem part of mints were tested. Rooting and number of rooting of spearmint and peppermint in water medium were more increased than in saprolite medium. But catmint was not rooted in any medium. Rooting of upper parts with growing points was more increased than under part of stem, which was relative hardy. In Rootone treatments test on rooting of stem cuttings, all treatments very strongly promoted the rooting and number of roots not only in upper stems but also in under part of stem in saprolite and water medium. Rootone treatments (drying 10 minutes after dipping on wetted stem) was very effective in water medium. Especially catmint treated with Rootone promoted a root formation in water medium This research was clarified the possibilities of rooting on spearmint, peppermint, and catmint cuttings in water medium, when especially treated with Rootone.
\end{abstract}

Keywords: aggregated medium, non aggregated medium, water medium

\section{Introduction}

Herbs were first introduced to Korean in 1986 along with western vegetables (Park, 2000), which did not receive much attention as the general public was not familiar with them. However, the liberalization of overseas travel in 1989 led to increased experience of foreign foods, and the interest in herbs have increased along with the improved national living standards (Park, 2007). The world's consumption analysis data shows a gradual increase in the demand for herbs, and their importance is also growing in the market (Lee, 2012). In particular, with more and more interest in healing such as aromatherapy, the world's total output of herbal essential oils reached over 22,000 tons, and processed goods using herbs also increased in addition to aromatherapy, such as perfume, soap, toothpaste and shampoo (EOAI, 2001; Lee, 2012).

Received: September 2, 2017, Revised: September 20, 2017, Accepted: October 23, 2017

*Comesponding author: flolin@hanmail.net 
Moreover, as more and more people have come to discover the functional effects of herbs on health such as digestive, antiseptic, antibacterial, anti-inflammatory, sterilizing and antioxidant effects, herbs are acknowledged as human-friendly natural plant resources and functional ingredients (Bouseta et al., 1996; De Smet, 1997), which led to greater demands (Lee, 2012). Koreans' favorite herbs in the 1990s were rosemary and mint (Shin, 2000), but recently mint has become third in line after rosemary and lavender. However, the annual mint plant bodies imported are over 100 tons, and essential oils over 60,000 tons that is the second-largest amount after orange oil, which shows how much of an important herb mint is (Lee, 2006; Lee, 2012). Despite the effects and the increasing use of mint, there is insufficient research on its vegetative reproduction. Therefore, to establish a mass propagation system of spearmint (Mentha spicata), peppermint (Mentha $\mathrm{x}$ piperita) and catmint (Nepeta cataria), this study brings light on the effects of substrate and rooting promoter (Rootone) and seeks new ways to cultivate mints in Korea.

\section{Research Method}

Labiatae such as pearmint (Mentha spicata), peppermint (Mentha $\mathrm{x}$ piperita) and catmint (Nepeta cataria) were used as materials for the experiment. Cutting slips were collected from Korea University Deokso Farm, and the experiment was conducted at the glasshouse of Korea University College of Life Sciences \& Biotechnology from March to May 2015. The cutting temperature was $20 \sim 25^{\circ} \mathrm{C}$, and shielding was done by about $70 \%$ using Gariso. The rest of the process in management was carried out in accordance with custom.

\section{Effects of substrates on rooting}

To find more economical substrates than those used in the rooting of the mint species, this study conducted a rooting experiment with substrates mixed with peatmoss based on the low-cost saprolite (10t/about 150 thousand KRW) that is relatively easy to obtain in Korea. Total 5 types of substrates were used in the experiment: saprolite, peatmoss, and three mixed substrates with different ratios of saprolite (Sa):peatmoss (Pe) such as 75:25, 50:50, 25:75 v/v. The result of particle size analysis of saprolite showed that it was typical saprolite including $22.68 \pm 1.94 \%$ gravels ( $2 \mathrm{~mm}$ or bigger), and Blumenerde (Germany, GRAMOFLOR Co.) was used for peatmoss. 90 cutting slips, 30 each with 3 repeats for 3 treatment plots ( 10 per treatment as 1 repeat), were cut for each of the five types of substrates, adding up to total 450 . The 105 cell plug tray was used, and management after cutting was done in accordance with custom. Two weeks after cutting, the rooting rate, number of roots for each individual, root length, and root fresh weight were measured. The ones longer than at least $1 \mathrm{~mm}$ were used to measure root length. To measure root fresh weight, the roots were separated and placed on a paper towel, and dried by gently pressing for 5 seconds, and then measured by $0.001 \mathrm{~g}$ using an electronic scale. A new paper towel was used for every measurement to avoid weight difference caused by water absorption.

\section{Effects of solid and non-solid medium on rooting}

Considering the cost reduction in propagation by cutting on saprolite in Experiment 1, saprolite was used by itself as solid medium (using 105 cell plug tray), and water (tap water in Seoul) that can be easily applied in home gardening was used as non-solid medium to compare the rooting patterns of mints. The water medium was fully replaced twice a week. Three types of cutting slips were divided into top stem with the growing point (removing all except 2-3 leaves including the growing point) and low stem (stem right below the top part that is cut off, removing all except 2-3 leaves), and total 180 cutting slips were cut on 2 types of substrates, 5 each for 3 repeats. Two weeks later, the cutting slips were dug out or 
taken out from the water, and rooting rate, number of roots, root length, root width, and root fresh weight were measured as in Experiment 1. Root thickness was measured by $0.01 \mathrm{~mm}$ using a caliper.

\section{Effects of hormones on rooting in solid medium}

To determine the effects of rooting promoter (Rootone) on rooting in solid medium saprolite, cutting slips were divided into top part and low part, and put into the 105 cell tray filled with saprolite. To keep the base of the cutting slips from drying, leveling was done for 1 hour and cutting slips were dust coated in a customary method using Dongbu Rootone (1-naphthylacetamide $0.4 \%$ ), after which they were put into the cutting bed. Total 270 cutting slips were cut, with 10 each for 3 repeats in the top part and 5 each for 3 repeats in the low part per mint. The same treatment and management was done as before. Two weeks later, rooting rate, number of roots, root length, root width, and root fresh weight were measured.

\section{Effects of hormones on rooting in liquid medium}

Since there is not enough literature to review regarding the rooting patterns with the Rootone treatment in liquid medium water, a preliminary test is conducted regarding the method and time for Rootone treatment on cut areas. In the test, cutting slips were put into water right after dust coating with Rootone, and most of Rootone fell apart into the water. Thus, to come up with a way to keep Rootone from falling apart from the stem for 2 weeks, we did not put the cutting slips into the water immediately after dust coating. Instead, we left them for 5-10 minutes so that Rootone gets stuck to the plant base before putting in the water. Rootone did not come off from the cutting slips in the cutting bed after leaving for 10 minutes, and it remained that way in the water for 2 weeks during the experiment.

Based on this result, we cut the stems in 45 degrees and coated the cut areas with Rootone dust after 1 hour of leveling, and put the cutting slips into the cutting bed after 10 minutes so that the dust sticks to the stem. They were put in the same way as fixing the plants on the growth cabinet for deep flow culture (Park and Lee, 1999), fixing the cutting slips with a sponge for rooting. Total 90 cutting slips were cut, 5 each for 3 repeats. Two weeks after the treatment, rooting rate, no. of roots, root length, root width, and root fresh weight were measured.

\section{Statistical analysis}

Each item was repeated 3 times, and for statistical analysis, significance test $(0.5 \%)$ was performed through between-treatment Turkey multiple range test using SAS Program.

\section{Results and Discussions}

\section{Effects of substrates on rooting}

We tested the effects of mixed substrates of saprolite and peatmoss on the rooting of 3 labiatae plants, and discovered that saprolite showed highest rooting rate and number of roots for peppermint and catmint, whereas rooting rate and number of roots were highest for spearmint in Sa:Pe 75:25, followed by saprolite. On the other hand, peatmoss showed the lowest rooting rate and number of roots (Table 1). Root length was high in Sa:Pe 75:25, 50:50 for both spearmint and peppermint. However, root fresh weight was $0.180 \mathrm{~g}$ in saprolite and $0.170 \mathrm{~g}$ in Sa:Pe 75:25 for spearmint, showing almost no difference, whereas for peppermint, root fresh weight was $0.310 \mathrm{~g}$ in saprolite and $0.230 \mathrm{~g}$ in Sa:Pe 75:25, showing a statistical difference. As for catmint, root fresh weight was $0.060 \mathrm{~g}$ in saprolite but $0.010 \mathrm{~g}$ in $\mathrm{Sa}: \mathrm{Pe} 75: 25$, also showing a 
Table 1. Effects of substrates on the rooting of mint species.

\begin{tabular}{cccccc}
\hline Labiatae & Medium & Rooting rate (\%) & No. of root (ea) & Root length $(\mathrm{cm})$ & Root F.W. (g) \\
\hline \multirow{5}{*}{ Spearmint } & Saprolite & $93.3 \pm 1.96^{\mathrm{z}} \mathrm{a}^{\mathrm{y}}$ & $14.8 \pm 0.83 \mathrm{ab}$ & $2.23 \pm 0.50 \mathrm{~cd}$ & $0.180 \pm 0.12 \mathrm{~b}$ \\
& Sa75 : Pe25 & $100.0 \pm 0.00 \mathrm{a}$ & $19.1 \pm 1.32 \mathrm{ab}$ & $5.23 \pm 0.61 \mathrm{a}$ & $0.170 \pm 0.04 \mathrm{~b}$ \\
& Sa50 : Pe50 & $93.3 \pm 1.96 \mathrm{a}$ & $13.2 \pm 1.13 \mathrm{~b}$ & $4.27 \pm 0.68 \mathrm{~b}$ & $0.200 \pm 0.08 \mathrm{ab}$ \\
& Sa25 : Pe75 & $90.0 \pm 1.83 \mathrm{a}$ & $11.1 \pm 0.68 \mathrm{bc}$ & $3.43 \pm 0.33 \mathrm{bc}$ & $0.147 \pm 0.05 \mathrm{c}$ \\
& Peatmoss & $56.7 \pm 2.90 \mathrm{~b}$ & $4.3 \pm 0.87 \mathrm{c}$ & $2.00 \pm 0.52 \mathrm{~d}$ & $0.036 \pm 0.03 \mathrm{e}$ \\
& Saprolite & $100.0 \pm 0.00 \mathrm{a}$ & $26.2 \pm 1.63 \mathrm{a}$ & $2.80 \pm 0.33 \mathrm{c}$ & $0.310 \pm 0.11 \mathrm{a}$ \\
& Sa75 : Pe25 & $93.3 \pm 1.39 \mathrm{a}$ & $16.3 \pm 1.03 \mathrm{ab}$ & $4.43 \pm 0.62 \mathrm{~b}$ & $0.230 \pm 0.06 \mathrm{~b}$ \\
& Sa50 : Pe50 & $96.7 \pm 1.39 \mathrm{a}$ & $14.6 \pm 1.19 \mathrm{ab}$ & $4.60 \pm 0.56 \mathrm{ab}$ & $0.200 \pm 0.08 \mathrm{bc}$ \\
& Sa25 : Pe75 & $76.7 \pm 1.39 \mathrm{ab}$ & $5.8 \pm 0.91 \mathrm{c}$ & $2.17 \pm 0.50 \mathrm{~d}$ & $0.093 \pm 0.06 \mathrm{e}$ \\
& Peatmoss & $73.3 \pm 1.96 \mathrm{ab}$ & $4.4 \pm 0.89 \mathrm{c}$ & $2.53 \pm 0.66 \mathrm{c}$ & $0.066 \pm 0.05 \mathrm{ef}$ \\
& Saprolite & $93.3 \pm 1.39 \mathrm{a}$ & $5.9 \pm 0.63 \mathrm{a}$ & $0.87 \pm 0.24 \mathrm{de}$ & $0.060 \pm 0.06 \mathrm{~cd}$ \\
& Sa75 : Pe25 & $30.0 \pm 2.40 \mathrm{c}$ & $1.7 \pm 0.67 \mathrm{~b}$ & $0.50 \pm 0.36 \mathrm{de}$ & $0.010 \pm 0.05 \mathrm{a}$ \\
& Sa50 : Pe50 & $46.7 \pm 1.96 \mathrm{bc}$ & $2.1 \pm 0.67 \mathrm{~b}$ & $0.70 \pm 0.40 \mathrm{de}$ & $0.010 \pm 0.02 \mathrm{be}$ \\
& Sa25 : Pe75 & $13.3 \pm 1.39 \mathrm{~d}$ & $0.4 \pm 0.24 \mathrm{c}$ & $0.10 \pm 0.14 \mathrm{e}$ & $0.003 \pm 0.03 \mathrm{~d}$ \\
& Peatmoss & $10.0 \pm 0.00 \mathrm{~d}$ & $0.5 \pm 0.47 \mathrm{c}$ & $0.07 \pm 0.13 \mathrm{e}$ & $0.003 \pm 0.05 \mathrm{~d}$ \\
\hline
\end{tabular}

${ }^{\mathrm{z}}$ The values represent mean \pm standard error $(\mathrm{n}=3)$.

${ }^{\mathrm{y}}$ Means separation with in columns in each plant by Turkey multiple range test at the $5 \%$ level.

statistical difference (Table 1). It has also been reported in a test on various mixtures of peatmoss with field soil made up of soil cement of reclaimed land that rosemary takes root best in mixed substrates than peatmoss alone (Han, 2001). The fact that number of roots, rooting rate and root fresh weight turned out to be higher in saprolite than other treatments suggests that important factors such as optimum moisture and void were better than other substrates. In general, saprolite in Korea is known to have a very high content of phosphoric acid (526 mg kg${ }^{-1}$ ) (Park et al., 2004), which implies that phosphoric acid may have had a positive effect on the initial formation of roots, and it has also been reported that phosphoric acid is highly effective for corn root growth (Mackay and Barber, 1986). As it has been reported that substrates with a lot of peatmoss rather hindered rooting due to high water holding capacity, moisture and oxygen perform a key role in rooting requirements, and thus the air permeability of the substrate determines the rooting of cutting slips (Park and Lee, 1999). Saprolite used in this experiment has $22.68 \pm 1.94 \%$ gravels at least the size of $2 \mathrm{~mm}$, and higher percentage of void than other mixed substrates may have served as a positive factor for rooting. The difference in rooting depending on the substrate properties in cutting is greatly affected by the void percentage of soil, and high water holding capacity rather hinders rooting (O'Neil and Carrow, 1983). The root length was higher in the treatment mixed with peatmoss than saprolite due to the difference in soil compaction. The physical properties of soil change the root length or root shape of carrots (Olymbios and Schwabe, 1977). Therefore, due to the physical resistance in saprolite, root length may have been suppressed than in substrates mixed with peatmoss.

Greater significance of this experiment is that it provided the possibility to use saprolite instead of peatmoss substrate for cutting substrate, which is imported at a high price by herb or horticultural farms (Park and Lee, 1999). If farms that mass-produce herb seedlings in Korea can purchase unpolluted saprolite to enhance the competitive edge of herb 
seedlings by lowering the prices and achieve effective rooting, it can be a good idea to use saprolite by itself or mixed with other treatments for vegetative propagation of herbs.

\section{Effects of solid and liquid medium on rooting}

Developing simpler and more convenient methods of herb rooting in home gardening will promote health through cultivation, with health effects such as aromatherapy in the broad sense. In this perspective, we conducted a rooting test using saprolite that brought good results in Experiment 1 as the solid medium (control medium), and water as the liquid medium.

The results showed that the number of roots was generally lower in water than saprolite for the top part of spearmint, but for the low part it increased to 15.3 in saprolite and 20.2 in water. Root length was longer in water for both spearmint and peppermint. For peppermint, both the top part and lower part showed a statistical difference in the number of roots in water (Table 2). As such, non-solid medium showed good effects on rooting and root length for spearmint and peppermint, whereas catmint did not show rooting on both the top part and lower part. As the Encyclopedia of Herbs by Bown introduces 25 types of mints and mentions that Mentha aquatica (watermint) shows good growth by the water (Bown, 1995), mints genetically tend to endure well underwater due to the differentiation of various species. On the other hand, catmint comes from a relatively dry area of Nepi near Rome and thus it has high drought tolerance but low moisture tolerance, thereby showing almost no rooting underwater. Spearmint and peppermint showed poor rooting on the lower part in saprolite, and this result is consistent with the study on parts of rosemary and lavender, which proved that top part stem cuttings including the growing point showed better rooting than the low part (Lee, 1999; Moon, 2015). This is generally due to the physiological properties of plants that have higher auxin content on the growing point than the lower part (Park and Lee, 1999).

In general, there is a difference in rooting depending on the amount of irrigation after cottage on solid medium due to

Table 2. Effects of aggregated medium (saprolite) and non-aggregated medium (water) on the rooting of mints.

\begin{tabular}{|c|c|c|c|c|c|c|c|}
\hline Med. & Part & Labiatae & Rooting rate (\%) & No. of root (ea) & Root length (cm) & Root width (mm) & Root F.W. (g) \\
\hline \multirow{6}{*}{$\begin{array}{l}\text { Aggregated } \\
\text { medium } \\
\text { (Saprolite) }\end{array}$} & \multirow{3}{*}{ Top } & Spearmint & $100.0 \pm 0.00^{\mathrm{z}} \mathrm{a}^{\mathrm{y}}$ & $20.5 \pm 1.16 \mathrm{a}$ & $3.67 \pm 0.36 \mathrm{a}$ & $0.81 \pm 0.11 \mathrm{a}$ & $0.104 \pm 0.07 \mathrm{a}$ \\
\hline & & Peppermint & $80.0 \pm 0.00 \mathrm{~b}$ & $22.5 \pm 1.50 \mathrm{a}$ & $4.20 \pm 0.75 \mathrm{a}$ & $0.53 \pm 0.28 \mathrm{a}$ & $0.202 \pm 0.13 \mathrm{a}$ \\
\hline & & Catmint & $40.0 \pm 0.00 \mathrm{c}$ & $1.9 \pm 0.15 b$ & $0.40 \pm 0.07 b$ & $0.26 \pm 0.03 a$ & $0.004 \pm 0.01 b$ \\
\hline & \multirow{3}{*}{ Lower } & Spearmint & $100.0 \pm 0.00 \mathrm{a}$ & $15.3 \pm 1.20 \mathrm{a}$ & $4.40 \pm 0.30 \mathrm{a}$ & $0.80 \pm 0.14 \mathrm{a}$ & $0.155 \pm 0.10 \mathrm{a}$ \\
\hline & & Peppermint & $100.0 \pm 0.00 \mathrm{a}$ & $10.9 \pm 0.62 \mathrm{ab}$ & $4.23 \pm 0.64 a$ & $0.77 \pm 0.10 \mathrm{a}$ & $0.120 \pm 0.05 a$ \\
\hline & & Catmint & $53.3 \pm 1.96 b$ & $4.3 \pm 1.11 b$ & $0.97 \pm 0.54 b$ & $0.49 \pm 0.40 \mathrm{a}$ & $0.029 \pm 0.09 b$ \\
\hline \multirow{6}{*}{$\begin{array}{l}\text { Non- } \\
\text { aggregated } \\
\text { medium } \\
\text { (Water) }\end{array}$} & \multirow{3}{*}{ Top } & Spearmint & $100.0 \pm 0.00 \mathrm{a}$ & $14.5 \pm 0.92 b$ & $4.97 \pm 0.28 \mathrm{a}$ & $0.87 \pm 0.15 \mathrm{a}$ & $0.111 \pm 0.07 b$ \\
\hline & & Peppermint & $100.0 \pm 0.00 \mathrm{a}$ & $26.0 \pm 1.26 \mathrm{a}$ & $4.83 \pm 0.80 \mathrm{a}$ & $0.69 \pm 0.17 b$ & $0.167 \pm 0.09 \mathrm{a}$ \\
\hline & & Catmint & $-{ }^{x}$ & - & - & - & - \\
\hline & \multirow{3}{*}{ Lower } & Spearmint & $100.0 \pm 0.00 \mathrm{a}$ & $20.2 \pm 1.4 \mathrm{a}$ & $4.90 \pm 0.23 b$ & $0.72 \pm 0.19 \mathrm{a}$ & $0.138 \pm 0.05 a$ \\
\hline & & Peppermint & $100.0 \pm 0.00 \mathrm{a}$ & $15.2 \pm 1.22 \mathrm{a}$ & $7.23 \pm 0.39 a$ & $0.69 \pm 0.13 \mathrm{a}$ & $0.146 \pm 0.08 \mathrm{a}$ \\
\hline & & Catmint & - & - & - & - & - \\
\hline
\end{tabular}

${ }^{\mathrm{z}}$ The values represent mean \pm standard error $(\mathrm{n}=3)$.

${ }^{\mathrm{y}}$ Means separation with in columns in each plant by Turkey multiple range test at the $5 \%$ level.

${ }^{\mathrm{x}}$ No measures do not rooting. 
the reaction between the moisture content difference in the substrate and the void (Park and Lee, 1999), and this may bring different results depending on the plants. But since the initial symptom of the leaves drying after cottage did not appear in water, it seems like a good method that can be applied to small home gardening.

\section{Effects of Rootone on rooting in solid medium}

To find a better way to promote rooting with saprolite that showed a significantly high rooting rate in Experiment 1, we experimented with Rootone treatment and obtained the following results. Both the top and low parts of the three types of cutting slips showed a remarkable increase in rooting in the treatment plot compared to control medium (Table 3, Fig. 1, 2). For spearmint, 15.3 top part cutting slips were rooted in control medium, while 41.1 cutting slips were rooted in Rootone treatment, which is three times more. The same results were found in low part cutting slips of spearmint and peppermint. For catmint that showed poor rooting in the previous experiment, 1.9 top part cutting slips in control medium increased to 7.1 in Rootone treatment, which is more than a three-fold increase.

As already well known, this is the result of rooting facilitated by Rootone, which is consistent with studies on Ficus (Kwack et al., 1989), oregano and marjoram (Kim, 2001), and rosemary (Han, 2001). This may be due to the fact that treating cutting slips with phytohormone (IBA) sends the substances required for the formation of adventitious roots to the base from the top part (Hartmann et al., 2010). Rooting on parts did not take root is a result of facilitating the generation of adventitious roots on tissues that are somewhat lignified, as the rooting promoter increases the auxin content in the plant cutting slips.

The fact that catmint, which shows poor rooting in general cutting, shows favorable rooting with Rootone treatment may serve as a good outcome that can be applied to herb farms or those with gardening as a hobby. Root length increased by more than 2-10 times after Rootone treatment, and root fresh weight also increased (Table 3). This is consistent with the finding of the rooting experiments (Im, 2011) on various herb species including woody herbs like rosemary (Han,

Table 3. Effects of Rootone treatments on the rooting of mints in saprolite.

\begin{tabular}{|c|c|c|c|c|c|c|}
\hline Med. & Part & Part & No. of Root (ea) & Root length (cm) & Root width (mm) & Root F.W. (g) \\
\hline \multirow{6}{*}{ Control } & \multirow{3}{*}{ Top } & Spearmint & $15.3 \pm 1.00^{\mathrm{z}} \mathrm{a}^{\mathrm{y}}$ & $1.50 \pm 0.21 b$ & $0.70 \pm 0.08 \mathrm{a}$ & $0.061 \pm 0.05 b$ \\
\hline & & Peppermint & $18.8 \pm 0.90 \mathrm{a}$ & $3.10 \pm 0.42 \mathrm{a}$ & $0.75 \pm 0.06 \mathrm{a}$ & $0.165 \pm 0.07 \mathrm{a}$ \\
\hline & & Catmint & $1.9 \pm 0.57 b$ & $0.17 \pm 0.57 \mathrm{c}$ & $0.18 \pm 0.09 b$ & $0.003 \pm 0.03 c$ \\
\hline & \multirow{3}{*}{ Low } & Spearmint & $0.7 \pm 0.20 b$ & $0.17 \pm 0.30 \mathrm{a}$ & $0.12 \pm 0.08 b$ & $0.002 \pm 0.03 a$ \\
\hline & & Peppermint & $1.8 \pm 0.37 \mathrm{ab}$ & $0.36 \pm 0.20 \mathrm{a}$ & $0.17 \pm 0.15 b$ & $0.004 \pm 0.05 \mathrm{a}$ \\
\hline & & Catmint & $2.4 \pm 0.54 \mathrm{a}$ & $0.27 \pm 0.14 \mathrm{a}$ & $0.28 \pm 0.04 a$ & $0.008 \pm 0.05 a$ \\
\hline \multirow{6}{*}{$\begin{array}{l}\text { Rootone } \\
\text { treatment }\end{array}$} & \multirow{3}{*}{ Top } & Spearmint & $41.1 \pm 2.15 \mathrm{a}$ & $1.97 \pm 0.16 b$ & $0.72 \pm 0.09 a$ & $0.165 \pm 0.08 b$ \\
\hline & & Peppermint & $34.1 \pm 0.55 \mathrm{a}$ & $2.70 \pm 0.24 a$ & $0.77 \pm 0.13 \mathrm{a}$ & $0.238 \pm 0.07 a$ \\
\hline & & Catmint & $7.1 \pm 1.38 b$ & $0.47 \pm 0.18 \mathrm{c}$ & $0.34 \pm 0.09 b$ & $0.023 \pm 0.05 c$ \\
\hline & \multirow{3}{*}{ Low } & Spearmint & $26.8 \pm 1.02 \mathrm{a}$ & $2.13 \pm 0.34 a$ & $0.75 \pm 0.22 \mathrm{a}$ & $0.117 \pm 0.10 b$ \\
\hline & & Peppermint & $29.0 \pm 1.28 \mathrm{a}$ & $3.37 \pm 0.55 \mathrm{a}$ & $0.87 \pm 0.18 \mathrm{a}$ & $0.240 \pm 0.12 \mathrm{a}$ \\
\hline & & Catmint & $7.6 \pm 0.93 b$ & $0.67 \pm 0.26 b$ & $0.42 \pm 0.13 b$ & $0.016 \pm 0.04 c$ \\
\hline
\end{tabular}

${ }^{\mathrm{z}}$ The values represent mean \pm standard error $(n=3)$.

${ }^{\mathrm{y}}$ Means separation with in columns in each plant by Turkey multiple range test at the $5 \%$ level. 


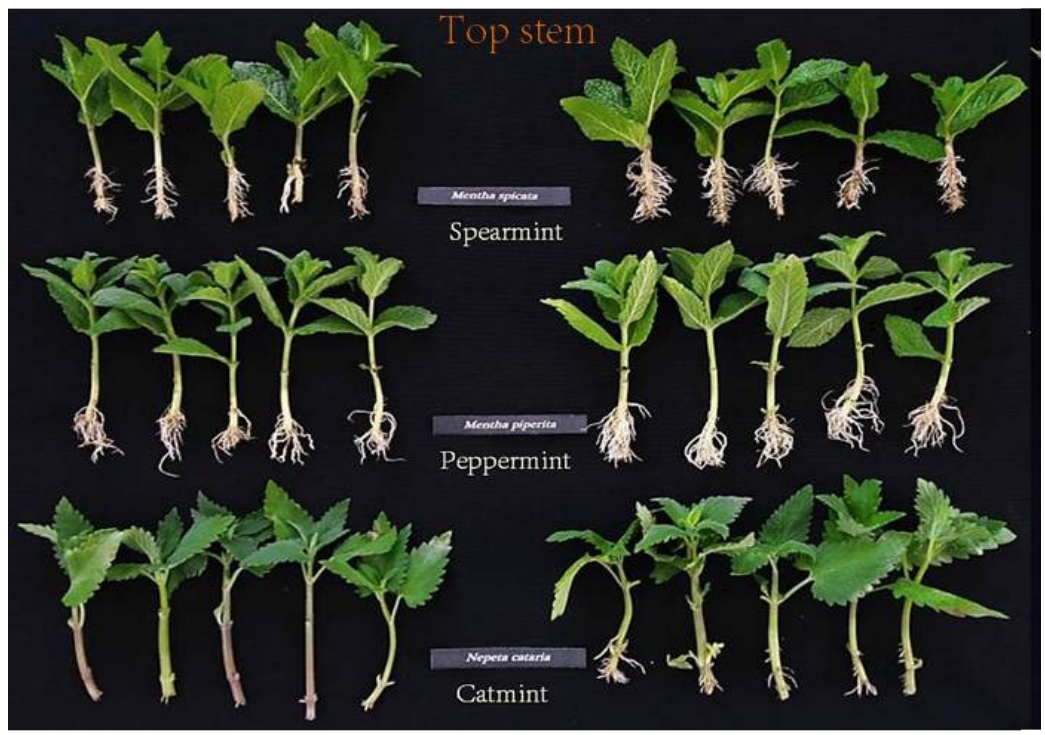

Figure 1. Effects of Rootone on the rooting shape of top stem of mints in saprolite (experimental group right, control group left).

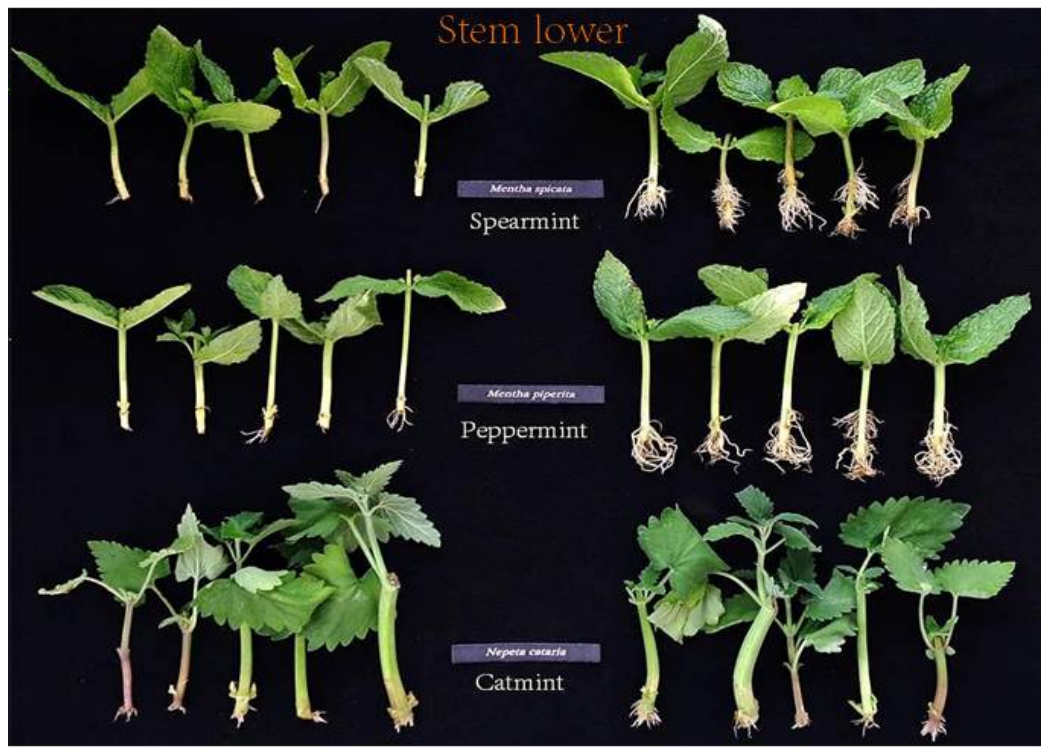

Figure 2. Effects of Rootone on the rooting shape of lower stem of mints in saprolite (experimental group right, control group left).

2001), herbaceous herbs like oregano and marjoram (Kim, 2001), and stevia (Chang, 2011), which discovered that Rootone promotes more effective root growth than other rooting promoters.

In particular, this study has great significance in that it provided the possibility that herb seedling farms can produce economical and strong seedlings if they use saprolite that is much lower in cost than peatmoss and perform cutting with Rootone.

\section{Effects of Rootone in liquid medium}

There have been no rooting test results in the water thus far, and herbs in particular had no cases in Korea. Thus, this 
study is significant in providing results of facilitating underwater rooting more easily in home gardening.

Compared to 3.2 for spearmint and 16.2 for peppermint in the control group, there were 46.8 for spearmint and 59.6 for peppermint in Rootone treatment, showing significant results by 15 times for spearmint and 4 times for peppermint. Catmint, which showed no rooting at all in non-solid medium test in Experiment 2 above, showed 1.3 roots. In other words, number of roots, root length, root width, and root weight all showed a statistical difference in Rootone treatment compared to control medium (Table 4 and Fig. 3).

The effects of Rootone in many solid mediums that have been carried out thus far (Kwack et al., 1989; Han et al., 2001; Kim, 2001; Han, 2001; Moon, 2015) were also found in liquid medium like water. However, for water rooting, attempts in terms of home gardening seem more appropriate than commercial use, and as it has been reported that oxygen and temperature of rooting zone in cutting have a great impact on rooting (Gislerod, 1982), water rooting treatment in mass propagation may raise other technical issues such as dissolved oxygen and water temperature by period, and thus requires various approaches in the future.

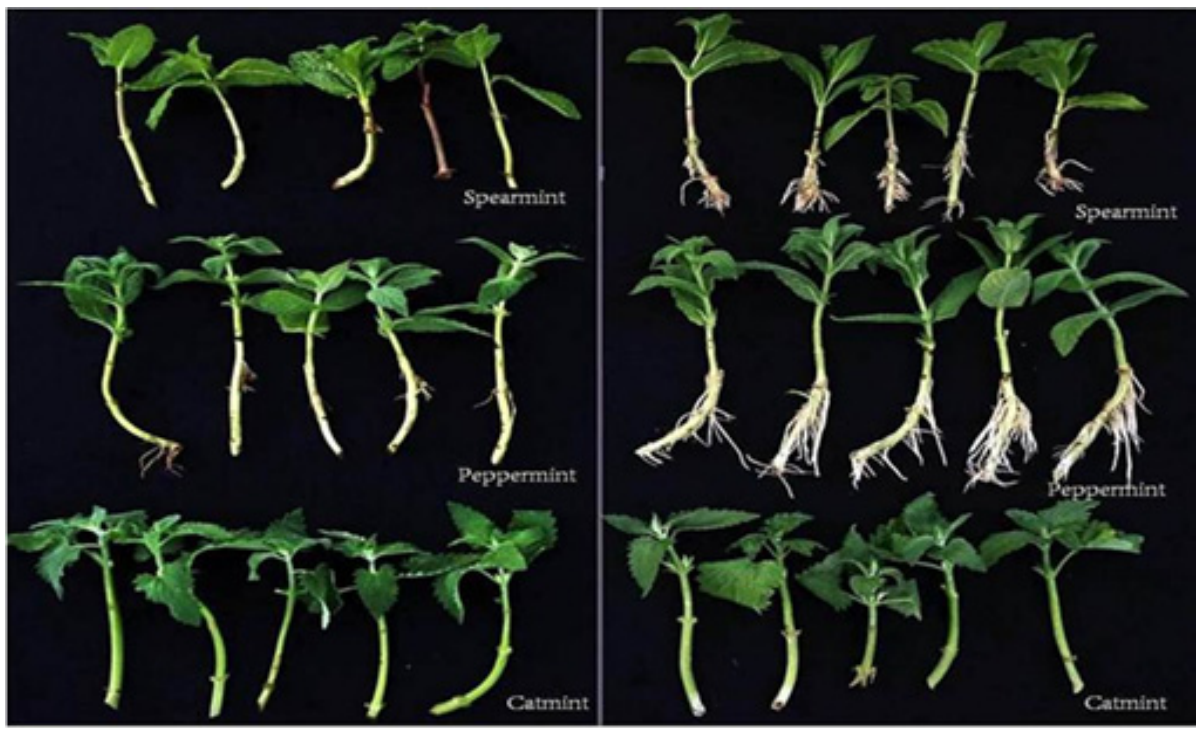

Figure 3. Effects of rootone treatments (drying 10 minutes after dipping on wetted stem) on the tooting shape of mints in water medium (experimental group right, control group left).

Table 4. Effects of Rootone treatment (drying 10 minutes after dipping on wetted stem) on the rooting of mints in water medium.

\begin{tabular}{lccccc}
\hline \multicolumn{1}{c}{ Medium } & Laviatae & No. of root $(\mathrm{ea})$ & Root length $(\mathrm{cm})$ & Root width $(\mathrm{mm})$ & Root F.W. $(\mathrm{g})$ \\
\hline \multirow{3}{*}{ Control } & Spearmint & $3.2 \pm 0.78^{\mathrm{z}} \mathrm{b}^{\mathrm{y}}$ & $0.57 \pm 0.26 \mathrm{~b}$ & $0.44 \pm 0.24 \mathrm{a}$ & $0.006 \pm 0.04 \mathrm{~b}$ \\
& Peppermint & $16.1 \pm 1.55 \mathrm{a}$ & $2.60 \pm 0.50 \mathrm{a}$ & $0.57 \pm 0.09 \mathrm{a}$ & $0.050 \pm 0.06 \mathrm{a}$ \\
& Catmint & $-^{\mathrm{x}}$ & - & - & - \\
\multirow{3}{*}{$\begin{array}{l}\text { Rootone } \\
\text { treatment }\end{array}$} & Spearmint & $46.8 \pm 1.13 \mathrm{~b}$ & $2.83 \pm 0.41 \mathrm{~b}$ & $0.80 \pm 0.17 \mathrm{a}$ & $0.140 \pm 0.05 \mathrm{~b}$ \\
& Peppermint & $59.6 \pm 1.56 \mathrm{a}$ & $4.87 \pm 0.35 \mathrm{a}$ & $0.91 \pm 0.17 \mathrm{a}$ & $0.316 \pm 0.18 \mathrm{a}$ \\
& Catmint & $1.2 \pm 0.20 \mathrm{c}$ & $0.16 \pm 0.16 \mathrm{c}$ & $0.15 \pm 0.17 \mathrm{~b}$ & $0.003 \pm 0.04 \mathrm{~b}$ \\
\hline
\end{tabular}

${ }^{\mathrm{z}}$ The values represent mean \pm standard error $(\mathrm{n}=3)$.

${ }^{\mathrm{y}}$ Means separation with in columns in each plant by Turkey multiple range test at the $5 \%$ level.

${ }^{\mathrm{x}}$ No measures do not rooting. 


\section{Conclusion}

The following results were obtained with the experiment on the effects of mixed substrates, non-solid medium, and rooting promoter on rooting, using spearmint, peppermint and catmint that are highly preferred by Koreans. Five types of substrates were used in the experiment: saprolite, peatmoss, and mixtures in the ratio of 75:25, 50:50, 25:75 (v/v). For peppermint and catmint, rooting rate and number of roots were significantly higher in saprolite compared to other treatments. Root length of spearmint was long in Sa:Pe 75:25, but showed no statistical significance with saprolite treatment. Root length of peppermint was long in Sa:Pe 75:25, 50:50 and root length of catmint was longest in saprolite. Rooting was generally poor in peatmoss and with treatments with a lot of peatmoss mixed in. However, root fresh weight was generally high in saprolite. In comparison of rooting patterns of cutting slips in each part in the solid medium sparolite and non-solid medium water, root length was long in water for spearmint and peppermint. In particular, the lower part showed a significant increase in the number of roots and root length than the top part (including the growing point) of cutting slips/ However, there was no rooting at all for catmint in the water for both the top and lower parts. Rootone treatment in solid medium saprolite accelerated rooting with statistical significance in the top and low part cutting slips of all three plants. In particular, Rootone treatment for catmint, which showed no rooting at all, ended up accelerating rooting in the water as well. Accordingly, this experiment presented the potential in using Rootone in underwater cutting for mints in the future.

\section{References}

Bouseta, A., V. Scheirman, and S. Colin. 1996. Flavor and free amino acid composition of lavender and eucalyptus honeys. J. Food Sci. 61(4):683-694. DOI: 10.1111/j.1365-2621.1996.tb12181.x

Bown, D. 1995. New encyclopedia of herbs \& their uses. London, UK: Dorling Kindersley.

Chang, K. H. 2011. Effect of substrates and plant growth regulator on the rooting of Stevia rebaudiana Bertoni. MS Thesis. Korea Univ., Seoul, Korea.

De Smet, P.A. 1997. The role of plant-derived drugs and herbal medicines in healthcare. Drugs 54(6):801-840. DOI: 10.2165/00003495-199754060-00003

EOAI (Essential Oils Association of India). 2001. Vision 2005. Mints. Retrieved from http://nhb.gov.in/Horticulture\% 20Crops\%5CMint\%5CMint1.htm.

Gislerod, H.R. 1982. Physical conditions of propagation media and their influence on the rooting of cuttings. I. Air content and oxygen diffusion at different moisture tensions. Plant Soil 69(3):445-456. DOI: 10.1007/BF02372465

Han, C.T., K.Y. Park, and J.P. Baek. 2001, October. Effect of substrate, rooting promoter and irrigation method on the root formation of rosemary (Rosemarinus officinalis) cutting. Poster session preseted at the $78^{\text {th }}$ Fall Conference on Korean Soc. Hortic. Sci., Korea.

Han, C.T. 2001. Effects of substrates rooting promoter and irrigation method on the root formation of rosemary cutting. MS Thesis Korea Univ., Seoul, Korea.

Hartmann, H.T., D.E. Kester, F.T. Davies Jr. and R.L. Geneve. 2010. Plant propagation: Principles and practices $8{ }^{\text {th }}$ Ed. Upper Saddle River, USA: Prentice-Hall Inc.

Im, M.W. 2011. Effects of cultivars, substrates and rooton on the rooting of thyme stem cutting. MS Thesis. Korea Univ., Seoul, Korea.

Kim, T.S. 2001. Effect of substrates and rooting promoter on rooting of marjoram (Origanum marjorana L.) and oregano (Origanum vulgare L.) cuttings. MS Thesis, Korea Univ., Seoul, Korea.

Kwack, B.H., D.B. Lee, and K.M. Lee. 1989. Effects of NAA, IBA and Ethychlozate on rooting of Ficus benjamina and 
Ficus nitida stem cuttings. J. Kor. Soc. Hort. Sci. 30(3):248-256.

Lee, C.H. 2012. Exports-imports and consumption pattern of herb and essential oils in Korea. MS Thesis, Korea Univ., Seoul, Korea.

Lee, G.H. 2006. Present status of internal and external export and import of spices. MS Thesis, Korea Univ., Seoul, Korea. Lee, J.N. 1999. Effect of cuttings and substrates on rooting of several herbs. MS thesis, Korea Univ., Seoul, Korea.

Moon, Y.H. 2015. Effects of cutting condition and rooting promoter on rooting of Trachelospermum asiaticum. MS Thesis. Korea Univ., Seoul, Korea.

Mackay, A.D. and S.A. Barber. 1986. Effect of nitrogen on root Growth of two corn genotypes in the field. Agronomy J. 78(4):699-703.

Olymbios, C.M. and W.W. Schwabe. 1977. Effect of aeration and soil compaction on growth of carrot, Daucus carota L. J. Hortic. Sci. 52(4):485-500. DOI: 10.1080/00221589.1977.11514779

O’Neil, K.J. and R.N. Carrow. 1983. Perennial ryegrass growth, water use, and soil aeration status under soil compaction. Agron. J. 75:177-180.

Park, K.W. 2000. Functional vegetable. Seoul, Korea: Herb world.

Park, K.W. 2007. Herb and aromatherapy.Seoul, Korea: Sunjinmunhwasa.

Park, K.W. and C.H. Lee. 1999. Horticulture propagation. Seoul, Korea: Sunjinmoonhwasa.

Park, C.S., Y.S. Jung, J.H. Joo, J.E. Yang. 2004. Soil characteristics of the saprolite piled upland fields at highland in Gangwon province. Korean. J. Soil. Sci. Fert. 37:66-73.

Shin, A.J. 2000. A study on the situation and development of herbal industry and aromatherapy in Korea. MS Thesis, Korea Univ., Seoul, Korea. 